\title{
TECHNOLOGICAL FORECASTING AS A TOOL FOR CURRICULUM DESIGN
}

\author{
J.A. Barrera Vera ${ }^{1}$, M. Castillo García ${ }^{2}$ \\ ${ }^{1}$ University of Seville (SPAIN) \\ ${ }^{2}$ Junta de Andalucía (SPAIN)
}

\begin{abstract}
One of the most important issues in education has to do with the updating process of curriculum. Many social and political reforms try to take steps in order to improve the educational system, but rarely do they tackle with one of the most important problems that education has nowadays: the increasingly fast obsolescence of the school curricula.
\end{abstract}

This concern is especially vital in fields that are directly related with technologies, like in different university degrees in engineering and subjects like technology in secondary school.

Our research group has been facing this problem for the las two years introducing a new technique in the subject "Educational innovation and research". The subject belongs to the MAES (University Master by the university of Seville for Secondary School Teachers) in the technology and industrial processes speciality.

There is a quite wide bibliography about technological forecasting applied to different areas like marketing, product design, etc. However, is not easy to find cases of study where this technique is applied to educational curriculum designing directly, or, if so, these cases are not sufficiently documented and published.

Nevertheless, fortunately there are some authors, such as Dimitry Kucharavy, that have carried out many studies and even in this case he has a specific subject about technology forecasting at the Politecnico di Milano [1]. Thus, we can extrapolate some procedures and theories to our students who are the people that have the important task of designing the curricula for the subject of technology in the Spanish secondary education for the near future.

Technological forecasting techniques allow our students to face the curriculum designing tasks with an extraordinary and skilful orientation. Furthermore, they give them an additional motivation in their work.

The aim of this paper is to describe the experience when introducing this technique in the last two academic years and discus the obtained results, as well as introducing the future prospects and the way forward in light of the speedy changes on technologies

Keywords: Technological forecasting, innovation, curriculum design.

\section{INTRODUCTION}

The experience has been carried out in the subject "Educational Innovation and Research" included in the MAES (Master by the University of Seville for Secondary School Teachers) in the technology and industrial processes speciality. The subject has a total workload of 6 ECTS (European Credit Transfer System) and is taught in two-hour sessions twice a week for two months.

The MAES is a master's degree which is compulsory in Spain for the secondary school teachers' career. Most of the Spanish Universities offer these studies and this subject is compulsory as well. Nevertheless, not all of them offer the speciality of "Technology and industrial processes", but when they do, the syllabus is very similar. Some examples of syllabus are shown in a selection of universities web sites [2] [3] [4] [5] [6].

All of them train students in pedagogical tools (Case Studies, Project Based Learning, Flipped Classroom, Gamification, etc.) and instrumental tools, with an emphasis on ICT tool. Furthermore, they introduce innovative techniques in their syllabus. However, none of them questions the suitability of the contents and the technology that is being taught. This reflexion is particularly important considering that we are training teachers for the future when these technologies presumably will be obsoletes. 
Consequently, we need a tool to forecast technology. There are many reasons to forecast in general and specifically, according to Joseph P. Martino, technological forecasting is unavoidable. Apart from many motivations given by the author, most of them "boil down to the idea of maximizing gain or minimizing loss from future conditions" [7]. In our case the gain is to adapt education to the knowledge of the right time.

Our ultimate goal by incorporating technological forecasting is to give the students, future secondary school teachers, an instrument that make them have a proactive attitude when designing their educational projects, so they suit the technology of the future instead of that one from the past.

\section{METHODOLOGY}

To start with, a conscious research about the syllabus taught along the Spanish universities has been carried out in order to detect if any similar approach has taken place.

Secondly, a complete documentation research about forecasting techniques has been retrieved and discussed [8].

After that the syllabus has been adapted giving special significance to technology and environmental changes by using forecasting techniques.

According to Makridakis, the steps we have followed in the forecast have been [9]:

1 Problem definition

2 Gathering information

3 Preliminary analysis

4 Choosing and fitting models

5 Using and evaluating a forecasting model

Once the full faculty have reached an agreement about the syllabus and the educational project, the real protagonist will be the student organized in 3to5-member groups.

One of the key practical activities in the master is an innovation project that students have to design to be implemented in a secondary school. They must decide the topic and the educational devices. In this phase is where the technological forecasting is introduced as a decision-making instrument.

The starting point has a double focus. On one side the study of the official current curricula of the subject "Technology" in secondary education. On the other side the faculty-oriented discussion about the role of technology in our society, paying especial attention to the impact of technology on global change.

Students, working in groups, are the protagonists of the process since, once they have been slightly trained in different techniques of technological forecasting, they choose the topic and, after been supported and preliminary assessed by the professor, they must carry out the project. This focus has extraordinary significance since technology is at the same time the source of environmental changes, that unfortunately are usually harmful, but also the solution to reduce the damage or improve the environment which was called by Paul Gray "The paradox of technological development" [10]. The feasible certainty of this "cause-and-effect relationship" empowers our determination to struggle to anticipate to the upcoming technology. In this sense, this strategy tries to foster policy-makers (in our case educational institutions) to overcome environmental surprises [11].

Finally, every single group makes a presentation the project to the rest of the class that is not only an spectator but also the evaluator, giving it a score which will be a part of the final assessment.

This sequence, after being revised and evaluated, has been repeated in a second course, but not before having modified several items according to the weaknesses and strengths detected.

\section{RESULTS}

When innovating, creative decisions are made. It makes wider the teaching meaning and involve the full staff of the institutions, regarding both the shared reflexion and practises design and development. This assertion inspired in Antonio Medina [12] condenses our feeling after evaluating the innovation carried out. So, we can summarize the results below. 


\subsection{Students' acceptance}

Despite the additional effort that the students have had to make to learn about forecasting methods and applications, they have had a collaborative attitude and they have been very benevolent in the final survey. We have to bear in mind that these students come from technical degrees (architects, building engineers, engineers and informatics), so they have no difficulties dealing with mathematical methods thanks to their previous training background.

\subsection{Impact in the subject and the master's degree}

Unfortunately, the impact of this innovation in the master's degree is not as great as looked for due to the fleeting subject where it has been carried out. The course lasts just two months and just 6 ECTS out of a total of 60 in the master.

\subsection{Degree of innovation reached}

Our research has not found any other case where this technique is being applied to curriculum design in technology in secondary school, which has supposed a surprising discovery. Since in secondary school are taught technology to students from 12 to 18 years old, the technology we are teaching in the first year (12 years old) would be used by the student, in the university or in their careers, 8 or 9 years later which is an eternity takin into account the speed of the technological change nowadays..

\subsection{Strengths and Weaknesses}

On one hand, the strongest point is the implication of students that were able to understand the proposal and get involved quickly in the innovation. They can see better than senior professor how important to teach updated technologies is because they themselves have suffered the fast obsolescence of the technological knowledge that they had learned in their degree. As an example, we can mention that they belong to a generation that was taught to design manually in the faculty and after finishing their degree they had to learn computer aided design (CAD) by themselves to update their knowledge to the professional reality. Thus, the student's motivation was excellent.

Additionally, the quality of the final projects has improved substantially in comparison of the previous courses, thanks to the high degree of innovation and originality shown.

On the other hand, the worst aspect has been the lack of time to perform a deeper implementation of the experience due to the few ETCS that the subject has been given in the master's degree program.

\section{CONCLUSIONS}

By introducing technological forecasting in decision-making, we have been able to give the future secondary school teachers, an instrument that make an interesting new skill in order to overcome obsoletes or out-of-date curriculums and achieve a new goal when designing their educational projects. Introducing technological forecasting techniques, the students not only have been more motivated but also the training achieved has made further strides than the traditional methodology.

Besides, in spite of the positive experience, the shortage of time for the subject has turned out significantly insufficient taking into account the additional effort that students have had to face in order to learn and practise technological forecasting to perform their projects.

We reckon the experience will pave the way for further implementation and will enhance the teaching and learning of this subject.

Regarding to the goal of enhancing the curriculum design task, according to the faculty's opinion and the results of the final survey, it has been reached satisfactorily. So, the next step should be convincing the educational authorities to introduce flexibility enough in the official curricula in order to accommodate this innovative focus.

\section{ACKNOWLEDGEMENTS}

This research could not have been possible without the priceless help given by Carlos Pagoda, Spanish engineer and former student of my department in the University of Seville, and by its former professor in the Politecnico di Milano, Dimitry Kucharavy who, by means of his subject "Technology 
Forecasting and Researching Future" and his Scientific Publications, paved the way to my research and my new focus in the subject "Educational innovation and research" at the University of Seville.

\section{REFERENCES}

[1] D. Kucharavy, Degree Programme, Politécnico di Milano, 2016-2017. Accessed 14 September 2018. Retrieved from

https://www4.ceda.polimi.it/manifesti/manifesti/controller/ManifestoPublic.do?EVN_DETTAGLIO RIGA_MANIFESTO $=$ evento\&aa $=2015 \& \mathrm{k} \_\mathrm{cf}=225 \& \mathrm{k}$ corso_la $=483 \& \mathrm{k}$ indir $=\mathrm{ME} 6 \mathbf{} \& \mathrm{codDescr}=0$

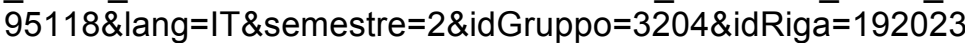

[2] Universidad de Málaga, Guía Docente de la Asignatura. 2018. Accessed 14 September 2018. Retrieved from https://oas.sci.uma.es:8443/ht/2018/ProgramasAsignaturas_Titulacion_5154_AsigUMA_101361 .pdf

[3] Universidad de La Rioja, Innovación Docente e Iniciación a la Investigación Educativa. Tecnología. Guía Docente Curso 2017-18. Accessed 14 September 2018. Retrieved from https://aps.unirioja.es/GuiasDocentes/servlet/agetguiapdf?2017-18,M07A,267206000

[4] Universidade da Coruña. Máster universitario en profesorado de educación secundaria obligatoria, bachillerato, formación profesional y enseñanza de idiomas. especialidad en ciencias experimentales (tecnología). 2018. Accessed 14 September 2018. Retrieved from http://estudos.udc.es/es/study/detail/437v02

[5] Universidad de Burgos, Guía Docente 2018-2019 Innovación Docente e Iniciación a la Investigación Educativa en Tecnologías. Accessed 14 September 2018. Retrieved from http://ubuvirtual.ubu.es/mod/guiadocente/get_guiadocente.php?asignatura=7846\&cursoacadem ico $=2018$

[6] Universidad de Murcia. Guía de la Asignatura de Máster "Innovación Docente e Iniciación a la Investigación: Modelos Didácticos en la Enseñanza de las Tecnologías" 2018/2019. Accessed 14 September 2018. Retrieved from https://aulavirtual.um.es/umugdocentetool/htmlprint/guia/RkJclH4RZWsV8omjlWqEQ1PjDUso94fh1VgJzYnrR23jIQqyvR2

[7] J. P. Martino, de Technological Forecasting for Decision Making, New York, Elsevier Science Publishing Co., Inc., 1983, pp. 4-12.

[8] M. Słupiński, Technology Forecasting-State of the art update. FORMAT consortium, 2013. Retrieved from http://www.format-project.eu/deliverables/public-reports-and-whitepapers/deliverable-2.3/view

[9] S. G. Makridakis, S. C. Wheelwright, \& R. J. Hyndman. Forecasting: Methods and applications, New York: Wiley, pp. 13-16, 2010.

[10] P. Gray, "The paradox of tehcnological development," in Technology and evironment, Washington DC, National Academy Press, 1989, pp. 192-204.

[11] A. Grübler, Technology and global change, Cambridge: Cambridge University Press, 2003.

[12] A. Medina Rivilla, M. C. Domínguez Garrido, \& C. Sánchez Romero, "The Innovation in the classroom: respect for the design and curriculum development" In Perspectiva Educacional, 50(1), 2011, pp. 61-8. 